\title{
PROFIL ZAT GIZI MIKRO (ZAT BESI, ZINK, VITAMIN A) DAN KADAR HEMOGLOBIN PADA IBU HAMIL
}

\author{
Micronutrient Profile (Iron, Zinc, Vitamin A) and Hemoglobin Level \\ in Pregnant Women
}

\author{
Ade Nugraheni ${ }^{1 *}$, Mutiara Prihatini ${ }^{1}$, Aya Yuriestia Arifin ${ }^{1}$, Fifi Retiaty ${ }^{1}$, Fitrah Ernawati ${ }^{1}$ \\ Puslitbang Biomedis danTeknologi Dasar Kesehatan Badan Litbang Kesehatan \\ Jalan Percetakan Negara Nomor 23 Jakarta Pusat, DKI Jakarta, Indonesia \\ *e-mail: nugraheniade@yahoo.com
}

Submitted: March 15 ${ }^{\text {th }}, 2021$, revised: May 21 ${ }^{\text {st }}, 2021$, approved: June $16^{\text {th }}, 2021$

\begin{abstract}
Background. Anemia in pregnant women is still a public health issue in Indonesia. Anemia in pregnant women can hurt the health of both the pregnant women and their unborn children. In developing countries such as Indonesia, the cause of anemia is partly due to lack of iron intake and other micronutrients such as zinc and vitamin A. Objective. The study aims to determine the micronutrient profile of pregnant women's serum and to assess the relationship between $\mathrm{Hb}$ levels and levels of sTfR, zinc, and vitamin A in pregnant women. Method. The study design was a cross-sectional part of the 2018 biomedical cohort study, which included 114 pregnant women ranging in age from 16 to 46 years old. The levels of Hb, sTfR, zinc, and vitamin A were all variables observed. SPSS version 18.0 was used to analyze the data, which included descriptive and Pearson correlation analysis. Results. The results showed that there were still pregnant women who were classified as at risk, namely in the age group 16-19 years as much as $5.3 \%$ and in the age group 41-46 years as much as 3.5\%. The 20-30 year age group had the highest rate of anemia, at $67.9 \%$, while the $31-40$ year age group had $33.0 \%$. In general, $35.1 \%$ of pregnant women were anemic, and $86.8 \%$ were zinc deficient. Conclusion. Level of sTFR, zinc, and vitamin $A$ are associated with Hemoglobin levels in pregnant women. To prevent anemia in pregnant women iron, zinc, and vitamin A levels must be improved, which can be accomplished by increasing zinc and vitamin A intake, particularly in pregnant women aged 20-30 years.
\end{abstract}

Keywords: anemia, micronutrients status, pregnant women, zinc deficiency

\begin{abstract}
ABSTRAK
Latar Belakang. Anemia pada ibu hamil sampai saat ini masih menjadi masalah kesehatan masyarakat di Indonesia. Anemia pada ibu hamil dapat berdampak pada kesehatan ibu hamil dan anak yang akan dilahirkan. Di negara sedang berkembang seperti di Indonesia penyebab anemia sebagian disebabkan kurang asupan zat besi, dan zat gizi mikro lainnya seperti zink dan vitamin A. Tujuan. penelitian ini bertujuan untuk meneliti profil zat gizi mikroserum ibu hamil dan melihat hubungan antara kadar $\mathrm{Hb}$ dengan kadar sTfR, zink, dan vitamin A pada ibu hamil. Metode. Desain penelitian ini adalah potong lintang yang merupakan bagian dari penelitian kohort biomedis tahun 2018 dengan subjek penelitian ibu hamil berusia 16-46 tahun sebanyak 114 sampel. Variabel yang diamati adalah kadar $\mathrm{Hb}$, sTfR, zink, dan vitamin A. Data dianalisis menggunakan SPSS versi 18.0 dengan uji deskriptif dan uji korelasi pearson. Hasil. Hasil penelitian menunjukkan bahwa masih terdapat ibu hamil yang tergolong pada usia berisiko, yaitu pada kelompok usia 16-19 tahun sebanyak 5,3\% dan kelompok usia 41-46 tahun sebanyak 3,5\%. Proporsi anemia pada ibu hamil tertinggi dijumpai pada kelompok usia 20-30 tahun yaitu 67,9\% dan kelompok usia $31-40$ yaitu $33,0 \%$. Secara umum ibu hamil mengalami anemia sebanyak $35,1 \%$ dan
\end{abstract}


kekurangan zink sebanyak 86,8\%. Kadar sTfR, zink, dan vitamin A berhubungan dengan kadar hemoglobin pada ibu hamil. Untuk mencegah anemia pada ibu hamil perlu perbaikan kadar besi, zink, dan vitamin A yang dapat dilakukan dengan meningkatkan asupan makanan sumber zat besi, zink, dan vitamin A khususnya pada ibu hamil usia 20-30 tahun.

Kata kunci: anemia, profil zat gizi mikro, ibu hamil, defisiensi zink

\section{PENDAHULUAN}

Status gizi ibu hamil sangat menentukan status gizi bayi yang akan dilahirkan. Anemia pada ibu hamil masih menjadi masalah kesehatan masyarakat di Indonesia. ${ }^{1}$ Hasil penelitian Riset Kesehatan Dasar (Riskesdas) tahun 2013 dan 2018 menunjukkan bahwa prevalensi anemia pada ibu hamil di Indonesia meningkat dari 37,1 persen ${ }^{2}$ menjadi 48,9 persen. ${ }^{3}$ Anemia tidak saja berdampak pada ibu hamil sendiri tetapi juga terhadap bayi yang dilahirkan, bahkan ibu yang mengalami anemia berpeluang besar melahirkan bayi dengan kekurangan zat besi walaupun tidak menderita anemia. Kekurangan zat besi pada anak jika dibiarkan dapat memengaruhi fungsi kognitif saat remaja dan dewasa. ${ }^{4,5}$

Penyebab anemia di negara sedang berkembang termasuk di Indonesia sebagian besar adalah kekurangan zat besi. Keadaan ini tidak hanya terjadi di Indonesia, tetapi di sebagian negara sedang berkembang yang daya beli penduduknya menjadi salah satu faktor pemicu. ${ }^{6}$ Sumber zat besi lebih banyak ditemukan di dalam pangan hewani daripada pangan nabati. Bioavailabilitas zat besi pada pangan nabati lebih rendah dibandingkan dengan bahan pangan hewani. Di samping itu, bahan pangan nabati mengandung zat antigizi seperti phitat yang akan mengganggu penyerapan zat besi. Peran dan fungsi zat besi antara lain adalah sebagai unsur hemoglobin, mioglobin, dan beberapa enzim oksidatif. Zat besi terdapat dalam semua sel tubuh, tetapi disimpan sebagai feritin dalam hati, limpa, dan sumsum tulang terutama dalam jaringan retikulo endothelial. Di dalam tubuh, zat besi berfungsi untuk mentransportasikan oksigen dan elektron serta merupakan bagian terpadu berbagai reaksi enzim seperti pada rantai pernapasan. Besi merupakan mineral mikro yang terbanyak dalam tubuh, yaitu sekitar 3-5 gram atau $40-50 \mathrm{mg} / \mathrm{kg}$ berat badan (BB) laki-laki dewasa dan 35-50 $\mathrm{mg} / \mathrm{kg}$ BB wanita dewasa. Pada bayi baru lahir level besi lebih tinggi, yaitu $70 \mathrm{mg} / \mathrm{kg} \mathrm{BB}{ }^{7}$

Kekurangan zat gizi mikro seperti besi, zink dan vitamin A pada ibu hamil patut mendapat perhatian. Vitamin A merupakan zat gizi mikro yang mempunyai peran besar dalam metabolisme zat besi dalam tubuh, ${ }^{8}$ demikian pula dengan kadar zink dalam kejadian anemia. Zink berperan pada lebih dari 200 enzim di dalam tubuh termasuk enzim yang membantu metabolisme zat besi. ${ }^{9}$ Zink dan zat besi sangat diperlukan untuk tumbuh kembang anak, dan apabila kekurangan zat gizi mikro ini terjadi sejak dalam kandungan maka akan berisiko anak lahir pendek. Riskesdas tahun 2018 melaporkan bahwa prevalensi anak pendek atau stunting di Indonesia mencapai 30,8 persen. Tingginya prevalensi stunting ini kemungkinan terjadi sejak dalam kandungan akibat ibu selama kehamilan kekurangan zat gizi mikro. Akibat defisiensi zat gizi mikro seperti zat besi, zink, dan vitamin 
A dapat memengaruhi kejadian stunting pada balita. ${ }^{10}$

Pemerintah telah memberikan tablet tambah darah sebagai upaya menurunkan prevalensi anemia ibu hamil. Tablet tambah darah (TTD) yang mengandung zat besi dan asam folat diberikan minimal 90 tablet selama masa kehamilan. Sementara upaya penanggulangan Kekurangan Vitamin A (KVA) dilakukan melalui suplementasi vitamin A atau Vitamin A supplementation (VAS) dalam bentuk pemberian kapsul vitamin A dosis tinggi pada ibu nifas sebesar $200.000 \mathrm{IU} .{ }^{11}$ Sementara itu, intervensi pemberian zink pada ibu hamil belum menjadi perhatian program kesehatan.

Sejumlah penelitian menyebutkan bahwa ibu hamil membutuhkan lebih dari sekedar zat besi dan asam folat sebagai asupan zat gizi mikro tambahan. Diperlukan zat gizi mikro tambahan lainnya yang lebih lengkap melalui suplemen multiple micronutrient (MMN) untuk ibu hamil. Suplemen MMN merupakan suplemen yang formulanya dibuat oleh UNICEF-WHO dengan kandungan 15 vitamin dan mineral antara lain vitamin A, C, D, E, B1 (tiamin), B2 (riboflavin), B3 (niasin), B6 (piridoksin), B12 (kobalamin), dan zink, asam folat serta zat besi (Fe) yang diperlukan bagi ibu hamil selama masa kehamilan. ${ }^{12,13}$

Penelitian ini merupakan bagian dari penelitian kohort biomedis pada tahun 2018 yang difokuskan untuk mengidentifikasi status gizi mikro (zat besi, zink, dan vitamin A) termasuk anemia pada ibu hamil. Tujuan penelitian adalah untuk meneliti profil zat gizi mikroserum yang dikaitkan dengan kadar hemoglobin pada ibu hamil untuk mencegah stunting pada usia dini.

\section{METODE}

Desain penelitian yang digunakan adalah potong lintang dengan menggunakan data primer dari sampel penelitian kohort biomedis tahun 2018. Lokasi penelitian berada di lima kelurahan (Kebon Kelapa, Babakan Pasar, Babakan, Ciwaringin, dan Panaragan) Kecamatan Bogor Tengah, Kota Bogor, Provinsi Jawa Barat. Populasi dalam penelitian adalah ibu hamil berumur lebih dari 16 tahun yang diperoleh dari rekrutmen sampel Studi Kohort Tumbuh Kembang Anak. ${ }^{14}$ Besar sampel dalam penelitian sebanyak 114 ibu hamil.

Spesimen pemeriksaan adalah serum yang berasal dari darah vena, selanjutnya dilakukan pemeriksaan kadar hemoglobin, sTFR, zink, dan vitamin A. Penelitian dilakukan di Laboratorium Gizi Badan Penelitian dan Pengembangan Kesehatan di Bogor pada bulan Maret sampai dengan Desember tahun 2018. Pemeriksaan kadar hemoglobin menggunakan metode cyanmeth dengan alat hematology analyzer Mindray, kadar sTFR diukur menggunakan metode ELISA dengan alat Microplate Reader Humalyzer, sementara kadar zink diukur menggunakan metode Atomic Absorbtion Spectrophotometer (AAS) dengan alat AAS Agilent AA280FS, dan kadar vitamin A diukur menggunakan metode High Performace Liquid Chromatography (HPLC) dengan alat HPLC Waters Alliance 2695. Validasi dilakukan dengan menggunakan serum reference material (SRM) untuk HB, sTFR, zink, dan vitamin A. Nilai normal $\mathrm{Hb}$ untuk ibu hamil adalah $\geq 11 \mathrm{~g} / \mathrm{dL}$, untuk sTFR adalah $8,7-28,1 \mathrm{nmoL} / \mathrm{L}$, zink adalah $\geq 0,7 \mathrm{mg} / \mathrm{L}$ dan vitamin $A$ adalah $\geq 20 \mathrm{mg} / \mathrm{dL}$. 
Hasil selanjutnya dianalisis dengan kelompok usia dan status anemia ibu hamil. uji deskriptif dan uji korelasi pearson Sementara uji korelasi Pearson untuk menggunakan SPSS versi 18.0. Uji deskriptif mengetahui hubungan status sTFR, zink, digunakan untuk mendapatkan nilai distribusi dan vitamin A dengan status anemia ibu sTFR, zink, dan vitamin A berdasarkan hamil.

\section{HASIL}

\section{Karakteristik Responden}

Tabel 1. Distribusi Ibu Hamil Berdasarkan Kelompok Usia

\begin{tabular}{lcc}
\hline \multicolumn{1}{c}{ Kelompok Usia } & $\mathrm{n}$ & $\%$ \\
\hline $16-19$ tahun & 6 & 5,3 \\
$20-30$ tahun & 66 & 67,9 \\
$31-40$ tahun & 38 & 33,0 \\
$41-46$ tahun & 4 & 3,5 \\
\hline Total & 114 & 100 \\
\hline
\end{tabular}

Tabel 1 menunjukkan bahwa sebagian besar responden yaitu 67,9 persen berusia antara 20-30 tahun diikuti usia 31-40 tahun sebanyak 33,0 persen. Data tersebut menunjukkan bahwa masih terdapat ibu hamil yang tergolong pada usia berisiko, yaitu pada kelompok usia 16-19 tahun sebanyak 5,3 persen dan kelompok usia 41-46 tahun sebanyak 3,5 persen.

Tabel 2. Distribusi Status Anemia Berdasarkan Kelompok Usia Ibu Hamil

\begin{tabular}{|c|c|c|c|c|c|c|}
\hline \multirow[t]{2}{*}{ Kelompok Usia } & \multicolumn{2}{|c|}{$\begin{array}{c}\text { Anemia } \\
(<11,0 \mathrm{mg} / \mathrm{dL})\end{array}$} & \multicolumn{2}{|c|}{$\begin{array}{l}\text { Tidak Anemia } \\
(\geq 11,0 \mathrm{mg} / \mathrm{dL})\end{array}$} & \multicolumn{2}{|c|}{ Total } \\
\hline & $\mathrm{n}$ & $\%$ & $\mathrm{n}$ & $\%$ & $\mathrm{n}$ & $\%$ \\
\hline 16-19 tahun & 1 & 2,5 & 5 & 6,8 & 6 & 5,3 \\
\hline 20-30 tahun & 50 & 62,5 & 41 & 55,4 & 66 & 57,9 \\
\hline $31-40$ tahun & 13 & 32,5 & 25 & 33,8 & 38 & 33,3 \\
\hline $41-46$ tahun & 1 & 2,5 & 3 & 4,1 & 4 & 3,5 \\
\hline Total & 40 & 100 & 74 & 100 & 114 & 100 \\
\hline
\end{tabular}

Tabel 2 menunjukkan bahwa berdasarkan kelompok usia, ibu hamil yang paling banyak mengalami anemia adalah ibu hamil pada kelompok usia 20-30 tahun yaitu 62,5 persen, diikuti ibu hamil usia 31-40 tahun yaitu 32,5 persen. 
Tabel 3. Distribusi Status Anemia, Besi, Zink, dan Vitamin A pada Ibu Hamil

\begin{tabular}{lcc}
\hline \multicolumn{1}{c}{ Variabel } & $\mathrm{n}$ & $\%$ \\
\hline Hemoglobin & $(114)$ & \\
Anemia $(<11,0 \mathrm{mg} / \mathrm{dL})$ & 40 & 35,1 \\
Normal $(\geq 11,0 \mathrm{mg} / \mathrm{dL})$ & 74 & 64,9 \\
Serum transferrin reseptor & & \\
Rendah $(<8,7 \mathrm{nmol} / \mathrm{L})$ & 19 & 16,7 \\
Normal $(8,7-28,1 \mathrm{nmol} / \mathrm{L})$ & 83 & 72,8 \\
Tinggi $(>28,2 \mathrm{nmol} / \mathrm{L})$ & 12 & 10,5 \\
Zink & & 86,8 \\
Defisiensi $(<0,7 \mathrm{mg} / \mathrm{L})$ & 99 & 13,2 \\
Normal $(\geq 0,7 \mathrm{mg} / \mathrm{dL})$ & 15 & 2,6 \\
Vitamin A & & 97,4 \\
Defisiensi $(<20 \mathrm{mg} / \mathrm{dL})$ & 3 & \\
Normal $(\geq 20 \mathrm{mg} / \mathrm{dL})$ & 111 & \\
\hline
\end{tabular}

Tabel 3 menunjukkan bahwa persentase ibu hamil yang mengalami anemia $(<11,0 \mathrm{mg} /$ $\mathrm{dL}$ ) sebesar 35,1 persen, sedangkan yang mengalami kekurangan zat besi (sTFR $>28,2$ $\mathrm{nmol} / \mathrm{L})$ adalah 10,5 persen. Selain itu Tabel
3 juga menunjukkan bahwa ibu hamil yang mengalami kekurangan zink (zink $<0,7 \mathrm{mg}$ / $\mathrm{dL})$ sebanyak 86,8 persen, sedangkan yang mengalami kekurangan vitamin $\mathrm{A}$ (vit $\mathrm{A}<20 \mathrm{mg} /$ $\mathrm{dL})$ sebesar 2,6 persen.

Tabel 4. Hubungan Kadar Hemoglobin dengan Kadar STfR, Zink, dan Vitamin A pada Ibu Hamil

\begin{tabular}{|c|c|c|c|c|}
\hline \multirow{2}{*}{ Kadar Zat Gizi Mikro } & \multirow{2}{*}{$\mathrm{n}$} & \multirow{2}{*}{ Rerata $\pm S D$} & \multicolumn{2}{|c|}{ Kadar Hemoglobin } \\
\hline & & & $r$ & $p$ \\
\hline sTfR (nmol/L) & 114 & $16,6 \pm 8,9$ & $-0,221$ & 0,018 \\
\hline Zink (mg/dL) & 114 & $0,58 \pm 0,12$ & 0,373 & 0,000 \\
\hline Vitamin A (mg/dL) & 114 & $37,4 \pm 10,1$ & 0,241 & 0,010 \\
\hline
\end{tabular}

Tabel 4 menunjukkan bahwa terdapat hubungan yang signifikan antara kadar hemoglobin dengan kadar zat besi (sTfR) ( $r=-$ $0,221 ; p<0,05)$, kadar hemoglobin dengan kadar zink $(r=0,373 ; p<0,05)$ dan kadar hemoglobin dengan kadar vitamin $\mathrm{A}(\mathrm{r}=0,241 ; p<0,05)$ pada ibu hamil. Hal ini menunjukkan bahwa untuk pencegahan anemia pada ibu hamil dapat dilakukan dengan memperbaiki kadar zat besi, zink, dan vitamin A. 


\section{PEMBAHASAN}

Kekurangan gizi mikro pada masa hamil dapat berdampak pada bayi yang dilahirkan. Salah satu dampak kekurangan zat gizi mikro pada masa kehamilan adalah anak lahir dengan berat badan rendah (BBLR) dan anak lahir pendek (stunting). ${ }^{15}$ Hasil penelitian ini menunjukkan bahwa masih terdapat ibu hamil yang masuk dalam usia kehamilan berisiko, yaitu sebanyak 5,3 persen ibu hamil dengan usia di bawah 20 tahun dan 3,5 persen usia di atas 40 tahun (Tabel 1). Usia reproduksi yang sehat dan aman pada perempuan adalah usia 20-35 tahun. ${ }^{16}$ Salah satu faktor masih adanya pernikahan usia dini di negara berkembang adalah kemiskinan. Orang tua beranggapan bahwa anak perempuan merupakan beban ekonomi sehingga untuk mempertahankan ekonomi keluarga, yaitu dengan cara menikahkan anak perempuannya pada usia dini. ${ }^{17}$ Di Indonesia pernikahan usia dini masih ada terutama di daerah perdesaan, dengan faktor yang melatarbelakangi adalah rendahnya tingkat pendidikan dan budaya. ${ }^{18}$ Selain itu, terdapat persentase ibu hamil pada usia 31-40 tahun yang cukup tinggi yaitu 33,0 persen. Ibu hamil dengan rentang usia yang mencakup usia yang berisiko tinggi yakni $>35$ tahun ini terjadi karena masih banyaknya pasangan yang memilih untuk menunda pernikahan dan melahirkan anak. ${ }^{19}$ Usia di bawah 20 tahun dan di atas 35 tahun disebut sebagai usia risiko tinggi untuk mengalami komplikasi selama kehamilan. Hal ini disebabkan pada usia kurang dari 20 tahun, ukuran uterus belum mencapai ukuran yang normal untuk kehamilan sehingga kemungkinan terjadinya gangguan dalam kehamilan seperti preeklampsia menjadi lebih besar. Sementara pada usia lebih dari 35 tahun terjadi proses degeneratif yang mengakibatkan perubahan sruktural dan fungsional yang terjadi pada pembuluh darah perifer yang bertanggung jawab terhadap perubahan tekanan darah, sehingga lebih rentan mengalami preeklampsia. ${ }^{20}$

Anemia didefinisikan sebagai berkurangnya kadar sel darah merah di dalam darah, yang ditandai dengan kadar hemoglobin $(\mathrm{Hb})$ di bawah ambang batas yang ditentukan. Ibu hamil dikategorikan mengalami anemia jika kadar hemoglobin darah kurang dari $11 \mathrm{~g} /$ dL. ${ }^{21}$ Berdasarkan kelompok usia, ibu hamil yang paling banyak menderita anemia adalah ibu hamil pada usia 20-30 tahun sebanyak 62,5 persen, kemudian disusul kelompok ibu hamil pada usia 31-40 tahun yaitu sebanyak 32,5 persen (Tabel 2). Hasil penelitian masih menemukan status anemia pada ibu hamil pada usia kehamilan berisiko yaitu usia kurang dari 20 tahun dan usia lebih dari 35 tahun (Tabel 2). Ibu hamil usia muda akan berisiko melahirkan anak BBLR dan stunting karena konsumsi zat gizi ibu yang seharusnya untuk tumbuh kembang anak masih diperlukan untuk pertumbuhan ibu sendiri sehingga akan mengganggu pertumbuhan anak dalam kandungan. Lebih lanjut, ibu hamil yang menderita anemia mempunyai risiko melahirkan anak dengan anemia. Oleh karena itu, ibu hamil berusia muda yang menderita anemia mempunyai risiko melahirkan anak BBLR yang menderita anemia. ${ }^{22}$

Usia remaja (<20 tahun) merupakan masa pertumbuhan yang pesat dengan kebutuhan tinggi akan zat gizi untuk mendukung pertumbuhan dan perkembangan yang optimum. Remaja putri adalah kelompok usia yang paling berisiko mengalami defisiensi zat besi. Pada periode ini, selain tubuh memerlukan zat besi lebih banyak untuk pertumbuhannya, kelompok 
usia ini juga sering mengalami kehilangan darah pada saat siklus menstruasi. Oleh karena itu pencegahan defisiensi besi dan anemia pada usia remaja sangat diperlukan untuk memberikan manfaat kesehatan dan perkembangan kognitif, juga akan memberikan manfaat bagi generasi mendatang. Diperkirakan bahwa setidaknya 25 persen wanita di negara berkembang memiliki anak pertama pada usia 19 tahun. Pada usia tersebut, wanita memulai kehamilan dengan hanya memiliki sedikit cadangan besi. Studi di Guatemala menyebutkan, 39 hingga 67 persen wanita tidak memiliki cadangan zat besi yang cukup. $^{23}$

Menurut World Health Organization (WHO), status besi dapat dilihat dengan melihat kadar sTfR. Kadar sTfR mencerminkan intensitas pembentukan sel darah merah sehingga dapat digunakan sebagai biomarker defisiensi besi. ${ }^{21}$ Pada saat kondisi anemia akibat kekurangan zat besi yang cadangan zat besi di dalam tubuh telah habis, konsentrasi sTfR akan meningkat pada membran plasma sel. ${ }^{24}$ Pada penelitian ini, ada 35,1 persen ibu hamil yang mengalami anemia $(\mathrm{Hb}<11,0 \mathrm{mg} / \mathrm{dL})$. Selanjutnya terdapat 10,5 persen ibu hamil mengalami anemia akibat kekurangan zat besi (Tabel 3). Hal ini kemungkinan disebabkan selama masa kehamilan, ibu hamil tersebut kurang mengonsumsi bahan pangan yang kaya akan zat besi. Zat besi diperlukan ibu hamil untuk meningkatkan jumlah sel darah merah dan membentuk sel darah merah janin dan plasenta. Apalagi pada ibu hamil muda (usia kurang dari 20 tahun), zat besi selain digunakan untuk pembentukan janin juga untuk pertumbuhan ibu hamil itu sendiri. Oleh karena itu, pemerintah melaksanakan program untuk membantu memenuhi kebutuhan zat besi dan asam folat tubuh berupa pemberian Tablet
Tambah Darah (TTD) selama masa kehamilan yang perlu ditingkatkan.

Anemia pada ibu hamil selain akibat kekurangan besi, juga dapat disebabkan karena kekurangan zat gizi mikro lainnya seperti zink (seng) yang akan mengakibatkan terjadinya hambatan pertumbuhan janin. Konsentrasi zink yang rendah pada plasma darah akan memengaruhi sirkulasi dari sejumlah hormon yang terkait dengan proses kehamilan seperti hormon progesteron dan estrogen. Rendahnya konsentrasi zink juga dapat menurunkan fungsi kekebalan tubuh sehingga akan meningkatkan kerentanan terhadap infeksi sistemik dan intrauterus. ${ }^{25}$

Hasil penelitian ini menunjukkan bahwa sebagian besar ibu hamil, yaitu sebesar 86,8 persen mengalami kekurangan zink (zink <0,7 $\mathrm{mg} / \mathrm{L}$ ) (Tabel 3). Tingginya persentase ibu hamil yang mengalami kekurangan zink perlu mendapat perhatian karena hal ini dapat menjadi faktor risiko anak lahir dengan kadar zink yang rendah. Zink memiliki peran besar untuk tumbuh kembang anak sehingga anak yang mempunyai kadar zink rendah akan berisiko mengalami gangguan pertumbuhan dan bila hal ini terjadi dan berlangsung lama dalam masa kehidupan anak maka anak akan tumbuh menjadi stunting. Dikatakan tubuh mengalami kekurangan zink jika kadar seng dalam plasenta $<0,7 \mathrm{mg} / \mathrm{L} .{ }^{26}$

Kecukupan asupan zink sangat tergantung dari jenis bahan pangan yang dikonsumsinya. Makanan kaya zat besi dan zink banyak dijumpai pada makanan hewani dan pangan hewani terutama daging merah yang mempunyai harga yang lebih mahal dibandingkan dengan pangan nabati. Sebagian besar responden berasal dari sosial ekonomi menengah ke bawah, sehingga 
mereka mempunyai keterbatasan ekonomi untuk membeli makanan hewani. Suzeta pada tahun 2007 menyatakan bahwa salah satu akibat dari kemiskinan adalah ketidakmampuan rumah tangga untuk memenuhi kebutuhan pangan dalam jumlah dan kualitas yang baik. ${ }^{27} \mathrm{Hal}$ ini berakibat pada kekurangan gizi termasuk zat gizi mikro. Penelitian Ernawati pada tahun 2006 juga menyatakan bahwa masalah utama penduduk miskin pada umumnya sangat tergantung pada pendapatan per hari yang biasanya tidak dapat memenuhi kebutuhan dasar secara normal. ${ }^{28}$ Penyediaan aneka ragam makanan dalam keluarga berkaitan erat dengan besar kecilnya pendapatan keluarga, harga bahan makanan itu sendiri, dan tingkat pengelolaan sumber daya lahan pekarangan. ${ }^{29,30,31} \mathrm{Hal}$ senada disampaikan juga oleh Proverawati dan Asfuah yang menyatakan bahwa keterbatasan penghasilan keluarga turut menentukan mutu makanan yang disajikan. ${ }^{32} \mathrm{Hal}$ tersebut juga sesuai dengan penelitian Imelda pada tahun 2018 yang menyebutkan harga merupakan salah satu faktor pertimbangan pada pemilihan makanan. ${ }^{33}$

World Health Organization (WHO) menetapkan defisiensi vitamin A tingkat sedang bila kadar serum retinol dalam darah 10-19,9 $\mathrm{gg} / \mathrm{dL}$ dan tingkat berat bila kadar serum retinol dalam darah $<10 \mu \mathrm{g} / \mathrm{dL} .{ }^{34}$ Ibu hamil yang kekurangan vitamin A akan mengakibatkan organ-organ janin tidak berkembang secara normal. Organ utama yang terpengaruh akibat kekurangan vitamin $A$ adalah sistem visual retina, telinga, kelenjar tiroid, jantung, saraf pusat, peredaran darah, sistem pernafasan, perkembangan tengkorak, dan anggota badan lainnya. ${ }^{35}$ Hasil penelitian menunjukan bahwa hampir semua ibu hamil tidak mengalami kekurangan vitamin A. Hanya 2,6 persen ibu hamil yang mengalami kekurangan vitamin $\mathrm{A}(<20 \mathrm{mg} / \mathrm{dL})$. Menurut WHO, angka ini masih dalam klasifikasi masalah kesehatan masyarakat ringan. ${ }^{36}$ Selain melalui program suplementasi vitamin A pada balita dan ibu nifas, program menanggulangi KVA juga dilakukan pemerintah melalui fortifikasi vitamin A pada bahan pangan. Kebanyakan susu serta makanan pabrikan sudah difortifikasi vitamin A. Semua program fortifikasi vitamin A tersebut, baik yang dilakukan oleh pemerintah maupun swasta diperkirakan akan semakin meningkatkan kadar serum retinol atau status vitamin A masyarakat Indonesia, termasuk ibu hamil. ${ }^{37}$

Pada penelitian ini dijumpai hubungan yang signifikan antara kadar hemoglobin dengan kadar zat besi (sTfR) $(r=-0,221 ; p<0,05)$, kadar hemoglobin dengan kadar zink $(r=0,373 ; p<0,05)$ dan kadar hemoglobin dengan kadar vitamin A $(r=0,241 ; p<0,05)$ pada ibu hamil. Hal ini menunjukkan bahwa untuk mencegah terjadinya anemia pada ibu hamil yang diindikasikan dengan meningkatnya kadar hemoglobin, adalah dengan memperbaiki kadar zat besi, zink, dan vitamin A. Hal ini sejalan dengan Baker dan Greer yang mengatakan bahwa anemia dapat terjadi akibat defisiensi zat besi, zink, dan vitamin A. ${ }^{38}$ Zat besi, zink, dan vitamin $A$ merupakan zat gizi mikro yang penting untuk pertumbuhan janin. Peran zink tidak secara langsung memengaruhi status anemia pada ibu hamil, tetapi sangat berperan dalam sintesi protein transferin, yaitu protein pengangkut besi. Jika seseorang mengalami defisiensi zink, sistem kekebalan tubuhnya menurun sehingga dapat mengakibatkan inflamasi. ${ }^{39,40}$ Kekurangan vitamin A juga memperburuk status anemia defisiensi besi (ADB). Beberapa penelitian menunjukkan bahwa terjadi interaksi vitamin 
A terhadap zat besi yang ditandai dengan menurunnya prevalensi anemia. ${ }^{41}$ Selain itu, jika ibu hamil dengan kekurangan zat gizi mikro berlangsung lama, maka akan berisiko anak yang lahir mengalami stunting. Beberapa penelitian menunjukkan bahwa defisiensi zink dan vitamin A dapat menyebabkan kegagalan pertumbuhan pada anak (stunting). Hal ini karena zink dan vitamin A berperan terhadap sintesis protein, yang diperlukan untuk proses pertumbuhan dan perkembangan sel. ${ }^{42}$

\section{KESIMPULAN}

Pada penelitian dijumpai proporsi ibu hamil yang mengalami anemia sebesar 35,1 persen dan kekurangan zink sebesar 86,8 persen. Kelompok usia ibu hamil terbesar yang mengalami anemia adalah usia 20-30 tahun. Ada hubungan yang signifikan antara kadar zat besi, zink, dan vitamin A dengan kadar hemoglobin, artinya memperbaiki kadar zat besi, zink, dan vitamin A dapat memperbaiki anemia Ibu hamil sehingga diharapkan dapat mencegah kejadian stunting pada usia dini.

\section{SARAN}

Untuk mencegah anemia pada ibu hamil terutama usia 20-30 tahun, perlu diperhatikan asupan gizi khususnya asupan sumber zink dan vitamin $\mathrm{A}$.

\section{UCAPAN TERIMA KASIH}

Penulis mengucapkan terima kasih kepada Kepala Satker Pusat Penelitian dan Pengembangan Biomedis dan Teknologi Dasar Kesehatan (PBTDK) yang telah memberikan dana penelitian Kohort Tumbuh Kembang Anak (TKA), serta kepada rekan-rekan peneliti dan litkayasa yang terlibat dalam penelitian ini, khususnya Dr. Fitrah Ernawati, M.Sc yang telah membimbing penulis dalam menyusun artikel ini.

\section{DAFTAR PUSTAKA}

1. Lynch, SR. Why Nutritional Iron Deficiency Persists as a Worldwide Problem. J Nutr. 2011;141(19):768.doi: https://doi. org/10.3945/jn.110.130609.

2. Badan Penelitian dan Pengembangan Kesehatan Kementerian Kesehatan RI. Laporan Riset Kesehatan Dasar (Riskesdas) Tahun 2013. Jakarta: Badan Penelitian dan Pengembangan Kesehatan Kementerian Kesehatan RI; 2013.

3. Badan Penelitian dan Pengembangan Kesehatan Kementerian Kesehatan RI. Laporan Riset Kesehatan Dasar (Riskesdas) Tahun 2018. Jakarta: Badan Penelitian dan Pengembangan Kesehatn Kementerian Kesehatan RI; 2018.

4. McCann JC, Ames BN. An Overview of Evidence for a Causal Relation Between Iron Deficiency During Development and Deficits in Cognitive or Behavioral Function. Am J Clin Nutr. 2007;85:931-45. 8 - 7

5. Kar BR, Rao SL, Chandramouli BA. Cognitive Development in Children with Chronic Protein Energy Malnutrition. Behav Brain Funct. 2008;4:31. http://dx.doi. org/10.1186/1744-9081-4-31.

6. Darmawati, Laila K, Kamil H, Tahlil T. The Relationship Between Socio-Economic Status with Iron Defficiency Anemia in Pregnant Women. Idea Nursing Journal. 2018;IX(3):6-13.

7. Yuniastuti A. Nutrisi Mikromineral dan Kesehatan. Semarang: Unnes Press; 2014. 
8. Semba RD, Bloem MW. The Anemia of Vitamin A Deficiency: Epidemiology and Pathogenesis. Eur J Clin Nutr. 2002;56(4):271-81.

9. lyengar V, Pullakhandam R, Nair KM. IronZinc Interaction During Uptake in Human Intestinal Caco-2 Cell Line: Kinetic Analyses and Possible Mechanism. Indian J Biochem and Biophys. 2009;46(4):299-306.

10. Damayanti RA, Muniroh L, Farapti. Perbedaan Tingkat Kecukupan Zat Gizi dan Riwayat Pemberian ASI Eksklusif pada Balita Stunting dan Non Stunting. Media Gizi Indonesia. 2016;11(1):61-9.

11. Kementerian Kesehatan RI. Peraturan Menteri Kesehatan Republik Indonesia Nomor 51 Tahun 2016 tentang Standar Produk Suplementasi Gizi. Jakarta;2016.

12. UNICEF, WHO, UNU. Composition of MultiMicronutrient Supplement to be used in Pilot Programmes among Pregnat Women in Developing Countries: Report of a United Nations Children's Fund (UNICEF)', World Health Organization (WHO) and United Nations University workshop. New York;1999.

13. Keats EC, Haider BA, Tam E, Bhutta ZA. Multiple-micronutrient Supplementation for Women during Pregnancy. Cochrane Database Syst. Rev. 2019;14(3):1-126. doi: 10.1002/14651858.CD004905.pub6.

14. Salimar, Irawati A, Besral. Maternal Height as an Determinant Factors of Children Not to be Stunting Until Age 59 Months. Indian Journal of Public Health Research and Development. 2019;10(3):765-71.
15. Zaif RM, Wijaya M, Hilmanto D. Hubungan antara Riwayat Status Gizi Ibu Masa Kehamilan dengan Pertumbuhan Anak Balita di Kecamatan Soreang Kabupaten Bandung. JSK.2017;2(3):156-63.

16. Astriana W. Kejadian Anemia pada Ibu Hamil Ditinjau dari Paritas dan Usia. Jurnal IImu Kesehatan. 2017;2(2):123-30.

17. The United Nations Children's Fund (UNICEF). Early Marriage: Factsheet. New York;2000.

18. Nurwati N. Review: Hasil Studi Tentang Perkawinan dan Perceraian pada Masyarakat Jawa Barat. Jurnal Kependudukan Padjadjaran. 2003;5(2):59-67.

19. Aghamohammadi A, Nooritajer M. Maternal Age as A Risk Factor for Pregnancy Outcomes: Maternal, Fetal and Neonatal Complication. Afr J Pharm Pharmacol. 2011;5(2):264-9.

20. El-Gilany AH, Hammad S. Obstetric Outcomes of Teenagers and Older Mothers: Experience from Saudi Arabia. International Journal of Collaborative Research on Internal Medicine and Public Health. 2012;4(6):9019.

21. World Health Organization. Assessing the Iron Status of Populations: Including Literature Reviews: Report of A Joint World Health Organization. Geneva;2007.

22. Pathak P, Kapil U, Kapoor SK, Saxena R, Kumar A, Gupta N, Dwivedis SN, et al. Prevalence of Multiple Micronutrient Deficiencies Amongst Pregnant Women in a Rural Area of Haryana. Indian J Pediatr. 2004;71:1007-14. 
23. Pan American Health Organization. Anemia Among Adolescent and Young Adult Women in Latin America and the Caribbean: a Cause for Concern. Washington: Pan American Health Organization;2007.

24. Ayu DZ. Pengaruh Suplementasi Glisin terhadap Kadar Serum Transferrin Receptor (sTfR) dan Haemoglobin (Hb). Jurnal Gizi Indonesia. 2015;4(1):22-7.

25. Danton-Hill I. Zinc Suplementation During Pregnancy. 2013. Diunduh dari: https:// www.who.int/elena/bbc/zinc_pregnancy/en/, tanggal 9 Maret 2021.

26. Gibson RS. Priciples of Nutritional Assesment. New York: Oxford University Press;2005.

27. Suzetta P. Bantuan hukum: Akses Masyarakat Marjinal terhadap Keadilan; Tinjauan Sejarah, Konsep Kebijakan, Penerapan dan Perbandingan di Berbagai Negara. Jakarta: LBH;2007.

28. Ernawati A. Hubungan Faktor Sosial Ekonomi, Higiene Sanitasi Lingkungan, Tingkat Konsumsi dan Infeksi dengan Status Gizi Anak Usia 2-5 Tahun di Kabupaten Semarang Tahun. Tesis. Semarang: Program Pascasarjana Universitas Diponegoro;2006.

29. Fikawati S, Syafiq A. Kajian Implementasi dan Kebijakan Air Susu Ibu Eksklusif dan Inisiasi Menyusu Dini di Indonesia. Makara Kesehatan. 2010;14(1):17-24.

30. Fikawati S, Syafiq A, Karima K. Gizi Ibu dan Bayi. Jakarta: PT. Raja Grafindo Persada;2015.

31. Fikawati S, Syafiq A. Status Gizi Ibu dan Persepsi Ketidakcukupan Air Susu Ibu.
Jurnal Kesehatan Masyarakat Nasional. 2012;6(6):249-54.

32. Proverawati A, Asfuah S. Buku Ajar Gizi untuk Kebidanan. Yogyakarta: Nuha Medika;2009.

33. Imelda. Karakteristik dan Pola Konsumsi Pangan Rumah Tangga Masyarakat Kota Pontianak. Ethos (Jurnal Penelitian dan Pengabdian Masyarakat). 2018;6(2):250-9.

34. World Health Organization. Indicators for Asessing Vitamin A Deficiency and Their Application in Monitoring and Evaluating Intervention Programers. Geneva: World Health Organization;1996.

35. Syah MNH, Thaha AR, Citrakesumasari. Status Zat Gizi Mikro (Besi, Asam Folat Dan Seng) Dan Kerusakan DNA Pada Anemia Ibu Hamil di Kecamatan Bontonompo dan Bontonompo Selatan Kabupaten Gowa Tahun 2012. Tesis. Makasar: Fakultas Kesehatan Masyarakat Universitas Hasanudin, 2013.

36. World Health Organization. Serum Retinol Concentrations for Determining The Prevalence of Vitamin A Deficiency in Populations. Geneva: World Health Organization; 2011. Diunduh dari https:// www.who.int/vmnis/indicators/retinol.pdf, tanggal 9 Maret 2021

37. Soekirman, Jus'at I. Food Fortification in Indonesia. Mal J Nutr. 2017;23(1):1-7.

38. Baker RD, Greer FR. Diagnosis and Prevention of Iron Deficiency and Irondeficiency Anemia in Infants and Young Children (0-3 years of age). Pediatrics. 2010;126(5):1040-50. 
39. Nixon P. Iron Transport, Storage and Overload in GMC Biochemistry Home Page. Biochemistry Departement. Queensland: The University of Queensland Australia, 2010.

40. Enig MG. Vitamin A for Fetal Development. 2010. Diunduh dari: https://www.aipro.info/ wp/wp-content/uploads/2017/08/vitaminA. pdf, tanggal 9 Maret 2021.
41. Garg A, Abrol P, Tewari A, Sen R, Lal H. Effect of Vitamin A Supplementation on Hematopoiesis in Children with Anemia. J Clin Biochem. 2005;20(1):85-6.

42. Gibney MJ, Margetts BM, Kearney JM, Arab L. Gizi Kesehatan Masyarakat. Jakarta: Penerbit Buku Kedokteran EGC; 2009. 